\title{
Studies on Vegetative Propagation of Some Guava Seedling Trees by Stem Cuttings As Influenced By Their Genotypes and Some Growth Regulators
}

Sharaf, M.M. ${ }^{1}$, Khamis, M.A. ${ }^{1}$, Bakry, KH.A. ${ }^{1}$, Saaed W.T. ${ }^{2}$ and EL-Tarawy, O.M. ${ }^{2}$

${ }^{1}$ Hort. Dept. Fac. Agric. Benha Univ., Egypt.

${ }^{2}$ Hort. Res. Inst., Giza, Egypt.

Corresponding author: osamaaltarawy@gmail.com

\begin{abstract}
This study was conducted in glass house at Horticulture Research Institute, Agricultural Research Centre, Giza during both 2018 and 2019 experimental seasons to investigate the possibility of using leafy wood stem cuttings of 10 selected guava seedlings trees for using to propagate them vegetatively. Whereas, rooting ability of their cuttings in response to genotypes and dipping in 4000 ppm IBA and 100 ppm TIBA were investigated. Besides some growth measurements i.e., number of both roots and shoots per rooted cuttings and their length, as well as No. of leaves per each and average leaf area were also included. Data obtained during both seasons cuttings of only five genotypes (seedling trees) succeeded to root while other fives completely failed. On the other hand ability of the leafy soft wood stem cutting of the five succeeded genotypes varied specifically from one seedling tree to another. Hence tree No. 10 was the superior while both $7^{\text {th }}$ and $8^{\text {th }}$ ones were the inferior and two other trees (No. 2 \& 6) were in between. The specific effect of growth regulators mired was also observed TIBA was more effective than IBA especially during $2^{\text {nd }}$ season whereas difference was significant. In addition, the most effective combination was always in closed relationship to the dipped cuttings of genotype 10 in TIBA 100 ppm fallowed by cuttings of the same trees treated by IBA $4000 \mathrm{ppm}$. Throe of dipped cuttings in either IBA or TIBA $100 \mathrm{ppm}$ for the $7^{\text {th }} \& 8^{\text {th }}$ trees were the inferior while other four combinations of two other trees $\left(2^{\underline{\text { nd }}} \& 6^{\text {th }}\right)$ were in between. The same trend was detected with the different growth measurements of the survived rooted cuttings of fire successed five genotypes with few exceptions scarcely observed during two seasons.
\end{abstract}

Keywords: Guava, Vegetative propagation, Stem cuttings, TIBA and IBA.

\section{Introduction}

The Guava (Psidium guajava L.) tree belongs to family Myrtaceae, comprising more than 70 genera and 2,800 species. The genus Psidium presents about 150 species (Guava fruits are delicious, rich in vitamin ' $\mathrm{C}$ ', carotene, thiamine, antioxidants, pectin and minerals like calcium, phosphorus and iron. Guava fruits are consumed as fresh fruits and industrial as jam, jelly, nectar etc. (Boora, 2012)) Guava may have originated either from tropical America or from Asia, and is now widespread throughout the tropics and subtropics. Guava is among the most drought resistant fruit groups. It grows on a wide range of soils provided they are relatively welldrained. Guava withstands acidic soils and is tolerant of shade (Ecocrop, 2015; CABI, 2013 and Orwa $\boldsymbol{e t}$ al., 2009). In Egypt, guava trees are grown in total area reached about 37398 Feddan and about 33512 Feddan fruiting orchards, yielding about 307535 tons (Anonymous, 2019).

The vast majority of cultivated guava trees are raised by seeds. As a result, trees vary greatly in growth, fruiting and fruit characteristics. The use of seed in propagating guava raised due to the difficulty of guava propagating vegetatively by traditional i.e. grafting, layering or stem cuttings. Such variances in seedling guava trees are considered the most important factor that limit the extension of guava plantation.

The propagation of guava by grafting has a limited success so far. Moreover, it is well known that the use of stem cuttings is the cheapest method of vegetative propagation (Hartmann, 1969). However, several investigators reported that guava stem cuttings are hard to root (Minessy et al., 1967 and El-Iraqy, 1994).

\section{Materials and Methods}

This experiment was conducted in the glass of glass house at Horticulture Research Institute, Agricultural Research Centre, Giza Governorate to investigated possibility of guava stem cuttings to root during both 2018 and 2019 experimental seasons. It was aimed to keep and perpetuate some selected seedling trees (genotypes) through realizing an acceptable and convenience cheap vegetative propagation methods. Hence rooting ability of leafy soft wood stem cuttings of desirable selected genotypes (12 \& 10) during $1^{\text {st }}$ and $2^{\text {nd }}$ seasons, respectively as influenced by specific and interaction effects of some pre planting dipping in (IBA \&TIBA) and the rooting nature of genotypes itself as well as their combinations. Consequently, the complete randomized block design with three replications (each replicate was represented by 6 cuttings) was employed for arranging the following treatments of two studied factors. Pre planting treatments (dipping for 30 seconds):

1- Tap water as control.

2- Indol butyric acid (IBA) at $4000 \mathrm{ppm}$.

3- Triiodo benzoic acid (TIBA) at $100 \mathrm{ppm}$.

So from each selected tree (genotype) i.e., 12 in 2018 season and 10 only in 2019 season 54 leafy soft 
wood stem cuttings ( 3 treatments $\times 3$ replicate $\times 6$ cuttings per each) were collected and prepared (20$25 \mathrm{~cm}$ length, $1.5 \mathrm{~cm}$ diameter and 2 leaves per each were left) as well as their bases were wounded.

After the leafy soft wood cuttings had been dipped in the corresponding pre planting solution they were immediately planted in plastic boxes filled with peat moss and sand mixture (1: 2 by volume) and kept under the intermittent mist for 100 days in the glass house. According to the seasonal and daily weather conditions the intermittent mist was programmed within a range of 2.5-5.0 minutes between sprays with mist duration of 5-10 seconds. Rooting ability was evaluated depending in differences exhibited after 100 days in the following measurements (rooting\%, number of roots \& shoots per cutting, average root and main shoots and average leaf area, whereas, planted cuttings were taken off, the successed rooted cuttings were individually transplanted in polyethylene bags filled with sand and peat moss at equal proportion and allowed to grow under the green house conditions for 12 weeks survival percentage was estimated:

Survival $\%=\frac{\text { No. of rooted cuttings remained alive }}{\text { No. of translocated rooted cutting allowed to grow }} \times 100$

\section{Anatomical structure:}

Samples were immediately killed and fixed in FAA solution. For softening, samples were soaked in tap water for 2 days before preparation of sections. Sections of about 18-20 microns in thickness were prepared by using a sledage microtome. The sections were stained by the safranine and fast green method (Johanson, 1940). Then sections were microscopically examined and photographed.

\section{Statistical analysis:}

All the obtained data in the two seasons of study were statistically analyzed using the analysis of variance (ANOVA) according to Snedecor and Cochran (1980). However, M. Static program was used to compare between means of treatments according to (Waller and Duncan, 1969) at probability of $5 \%$.

\section{Results and Discussions}

In this respect specific and interaction effects of both investigated factors (preplanting dipping in some growth regulators solutions \& genotypic nature of the selected guava trees) and their combinations on stem cutting rooting ability of the selected guava seedling trees were evaluated during 2018 \& 2019 experimental seasons. Success of propagating such selected guava genotypes vegetatively by the leafy soft wood stem cuttings as influenced by the investigated treatments (2 factors) was evaluated through comparison between variances exhibited in the following measurements related to such target.
Data obtained during both seasons are presented in Tables (1), (2), (3), (4), (5), (6), (7) and (8). 1. Rooting \% of guava leafy stem cuttings: A. Specific effect:

Table (1) displays obviously that rooting $\%$ of guava leafy stem cuttings responded specifically to the different treatments of both investigated factors. Herein, preplanting treatments of dipping in 4000ppm IBA and $100 \mathrm{ppm}$ TIBA ( $1^{\text {st }}$ factors) increased significantly rooting $\%$ of guava stem cuttings over control (dipping in tap water) which completely failed to root. However, TIBA at $100 \mathrm{ppm}$ was more effective and significantly surpassed 4000 ppm IBA especially during $2^{\text {nd }} 2019$ experimental season.

As for the specific effect of guava genotypes, it was quite clear that the selected seedling trees i.e., (12) $\&$ (10) during $1^{\text {st }} \& 2^{\text {nd }}$ seasons respectively varied obviously in their rootability as compared each other during two seasons. Since genotype of the $2^{\frac{\text { nd }}{d}}, 6^{\text {th }}, 7^{\text {th }}$, $8^{\text {th }}$ and $10^{\text {th }}$ codes showed a variable degree of success in rooting ability of their leafy soft wood stem cuttings. Whereas, tree number 10 exhibited statistically the highest rooting\% i.e., (36.66 \& $31.11 \%)$ or $(33.88 \%)$ as data of either $\left(1 \pm\right.$ st $\& 2^{\text {nd }}$ seasons) or an average of two seasons were concerned, respectively. On the contrast, trees (No $7 \& 8$ ) \& No 2 showed the least rooting $\%$ during $1^{\text {st }} \& 2^{\text {nd }}$ seasons, respectively. In addition, other succeeded genotypes to root identically (No 2, 6 and 7) were in between the aforesaid two extremes with a relative tendency of higher rooting\% exhibited by genotype No 6 .

\section{B. Interaction effect:}

Table (1) displays that, each investigated factor (preplanting dipping in growth regulators solutions \& guava genotype) had been reflected directly its own specific effect on their possible combinations. Accordingly, the highest rooting\% was always in closed relationship to the preplanting dipped cuttings of genotype 10 in $100 \mathrm{ppm}$ TIBA solution which exhibited rooting ability of $60.00 \% \& 53.33 \%$ during 2018 \& 2019 seasons, respectively. Moreover, dipping the leafy soft wood stem cuttings of the same genotype (code 10 tree) in the 4000 ppm IBA come second, however differences between two combinations (dipped leafy stem cuttings of genotype code 10 in 100 ppm TIBA and 4000 ppm IBA didn't reach level of significance during both seasons. In addition, dipping in 100 ppm TIBA of stem cuttings prepared from guava tree number 7 (genotype 7) also showed statistically a comparable rooting $\%$ value to that previously detected with both superior combinations during $2^{\text {nd }} 2019$ season. On the other hand, other combinations showed significantly lower rooting\% then the analogous ones of the aforesaid 3 superior combination, with a relative tendency of variance observed from one season to another efficiency of such category were compared each other during both 2018 \& 2019 seasons. 
Accordingly as an average of two seasons was concerned it could be safely concluded that dipped cuttings of $10^{\text {th }}$ genotype in 100 ppm TIBA was the superior furrowed by dipping cuttings of the same selected tree in 4000 ppm IBA ( $\left.2^{\text {nd }}\right)$, descendly followed by dipping cuttings of 7 th genotype in 100 ppm TIBA ( $3^{\text {rd }}$ ) and dipping $2^{\text {nd }}$ genotype cuttings in $100 \mathrm{ppm}$ TIBA. The aforesaid four combinations exhibited an average rooting $\%$ of about 56.67, 45.00, 40 and $36.67 \%$, respectively as an average of two seasons was concerned. On the contrary the least rooting \% value of two seasons average was coupled with dipping cuttings of $7^{\text {th }}$ tree in 4000 ppm IBA
(26.67\%) followed in an ascending order by $8^{\text {th }}$ genotype cuttings in $4000 \mathrm{ppm}$ (28.33\%) and dipping cuttings of either $8^{\text {th }}$ tree in 100 ppm TIBA or $2^{\text {nd }}$ tree cuttings in 4000 ppm IBA (approximately 30\%).

Such results are in general agreement with the finding of El-Iraqy (1994) regarding the differences between plant kinds in their rooting ability. Besides, the present result regarding the influence of growth regulators on stem cuttings rooting ability and variances in their capability in this regard are in congeniality with those found by Abdullah et al., (2006); Samaan et al, (2010); Kareem et al, (2013) and Abdul Kareem et al, (2016).

Table 1. Rooting percentage of guava leafy soft wood stem cuttings in response to specific and interaction effects of genotype (seedling trees) and preplanting treatments of dipping in some growth regulators during 2018 and 2019 seasons.

\begin{tabular}{|c|c|c|c|c|c|c|c|c|}
\hline \multirow{3}{*}{$\begin{array}{l}\text { Dipping } \\
\text { treatments } \\
\text { Genotype } \\
\text { (seedling } \\
\text { tree) code }\end{array}$} & \multicolumn{8}{|c|}{ Rooting \% of leafy soft wood stem cuttings } \\
\hline & \multicolumn{3}{|c|}{ 1st season } & \multirow[b]{2}{*}{ Mean * } & \multicolumn{3}{|c|}{ 2므 season } & \multirow[b]{2}{*}{ Mean * } \\
\hline & Control & $\begin{array}{l}\text { IBA } \\
4000 \\
\text { ppm }\end{array}$ & $\begin{array}{c}\text { TIBA } \\
\text { 100ppm }\end{array}$ & & Control & $\begin{array}{l}\text { IBA } \\
4000 \\
\text { ppm }\end{array}$ & $\begin{array}{c}\text { TIBA } \\
100 \\
\text { ppm } \\
\end{array}$ & \\
\hline 1 & $0.00 \mathrm{e}$ & $0.00 \mathrm{e}$ & $0.00 \mathrm{e}$ & $0.00 \mathrm{D}$ & $0.00 \mathrm{~d}$ & $0.00 \mathrm{~d}$ & $0.00 \mathrm{~d}$ & $0.00 \mathrm{C}$ \\
\hline 2 & $0.00 \mathrm{e}$ & $40.00 \mathrm{bc}$ & $40.00 \mathrm{bc}$ & $26.66 \mathrm{~B}$ & $0.00 \mathrm{~d}$ & $20.00 \mathrm{c}$ & $33.33 \mathrm{bc}$ & 17.77 B \\
\hline 3 & $0.00 \mathrm{e}$ & $0.00 \mathrm{e}$ & $0.00 \mathrm{e}$ & $0.00 \mathrm{D}$ & $0.00 \mathrm{~d}$ & $0.00 \mathrm{~d}$ & $0.00 \mathrm{~d}$ & $0.00 \mathrm{C}$ \\
\hline 4 & $0.00 \mathrm{e}$ & $0.00 \mathrm{e}$ & $0.00 \mathrm{e}$ & $0.00 \mathrm{D}$ & $0.00 \mathrm{~d}$ & $0.00 \mathrm{~d}$ & $0.00 \mathrm{~d}$ & $0.00 \mathrm{C}$ \\
\hline 5 & $0.00 \mathrm{e}$ & $0.00 \mathrm{e}$ & $0.00 \mathrm{e}$ & 0.00 D & $0.00 \mathrm{~d}$ & $0.00 \mathrm{~d}$ & $0.00 \mathrm{~d}$ & $0.00 \mathrm{C}$ \\
\hline 6 & $0.00 \mathrm{e}$ & $40.00 \mathrm{bc}$ & $46.66 \mathrm{~b}$ & 28.88 B & $0.00 \mathrm{~d}$ & $26.66 \mathrm{bc}$ & $23.33 \mathrm{bc}$ & 20.00 B \\
\hline 7 & $0.00 \mathrm{e}$ & $20.00 \mathrm{~d}$ & $26.66 \mathrm{~d}$ & $15.55 \mathrm{C}$ & $0.00 \mathrm{~d}$ & $20.00 \mathrm{c}$ & $53.33 \mathrm{a}$ & 24.44AB \\
\hline 8 & $0.00 \mathrm{e}$ & $30.00 \mathrm{~cd}$ & $26.66 \mathrm{~d}$ & $18.88 \mathrm{C}$ & $0.00 \mathrm{~d}$ & $26.66 \mathrm{bc}$ & $33.33 \mathrm{bc}$ & 20.00 B \\
\hline 9 & $0.00 \mathrm{e}$ & $0.00 \mathrm{e}$ & $0.00 \mathrm{e}$ & $0.00 \mathrm{D}$ & $0.00 \mathrm{~d}$ & $0.00 \mathrm{~d}$ & $0.00 \mathrm{~d}$ & $0.00 \mathrm{C}$ \\
\hline 10 & $0.00 \mathrm{e}$ & $50.00 \mathrm{ab}$ & $60.00 \mathrm{a}$ & $36.66 \mathrm{~A}$ & $0.00 \mathrm{~d}$ & $40.00 \mathrm{ab}$ & $53.33 \mathrm{a}$ & $31.11 \mathrm{~A}$ \\
\hline 11 & $0.00 \mathrm{e}$ & $0.00 \mathrm{e}$ & $0.00 \mathrm{e}$ & 0.00 D & - & - & - & - \\
\hline 12 & $0.00 \mathrm{e}$ & $0.00 \mathrm{e}$ & $0.00 \mathrm{e}$ & 0.00 D & - & - & - & - \\
\hline Mean ** & $0.00 \mathrm{~B}$ & $15.00 \mathrm{~A}$ & $16.67 \mathrm{~A}$ & & $0.00 \mathrm{C}$ & 11.11 B & $16.39 \mathrm{~A}$ & \\
\hline
\end{tabular}

*, ** refer to specific effect of seedling tree genotype and growth regulators treatment respectively Means of each investigated factor or their combinations followed by the same letter/s are not significantly different at $5 \%$ level.

2. Evaluation of guava rooted cuttings produced by the genotype. Whereas guava genotypes code (10) five genotypes succeeded to root:

In this concern number of (roots, shoots, leaves) per rooted cutting average length of both (root \& shoot) leaf area and survival\% were the seven investigated parameters of the rooted cutting of the five guava genotypes succeeded to root in as influenced by specific and interaction effects two investigated factors (preplanting treatments \& guava genotypes) and their combinations.

\section{1. Number of initiated adventurous root / rooted} cutting:

\section{A. Specific effect:}

It is quite evident as shown from tabulated data in Table (2) that No of roots per rooted cutting was specifically affected by both investigated factors. Herein, dipping in 100 ppm TIAB was statistically the most effective followed by $4000 \mathrm{ppm}$ IBA. On the other hand, Table (2) shows also that number of roots influenced obviously by the specific effect of guava surpassed significantly the four other genotypes succeeded to root descendly followed by genotypes (7), (6), (8) and (2) which ranked last. Such trend was true during both 2018 \& 2019 experimental seasons as specific effect of each investigated factor was concerned. Deferens were significant with a unique exception observed during 1 st season, while specific effect of both $6^{\text {th }} \& 7^{\text {th }}$ genotypes compered each other, whereas difference didn't reach level of significance.

\section{B. Interaction effect:}

Table (2) and photo (1) reveals obviously that, specific effect of each investigated factor reflected directly on their possible combinations. Herein, dipping leafy stem cuttings of guava genotype (10) either in $100 \mathrm{ppm}$ TIBA or to great extent in $4000 \mathrm{ppm}$ IBA resulted statistically in the greatest number of roots per rooted cutting, descendly followed by dipping leafy soft wood stem cuttings both (6) and (7) 
genotypes in 100 ppm TIBA. The reverse was true with dipping stem cuttings of genotype (2) in either 4000 ppm IBA \& 100 ppm TIBA especially $1^{\text {st }}$ solution whereas the least number of roots/ rooted cutting was detected. In addition other combinations were in between the above mentioned two extreme.

These results are in harmony with findings of Bacarin et al., (1994); Souidan et al., (1995) and Maurya et al. (2012).

Table 2. Number of roots per rooted cutting of five guava genotypes succeed to root as affected by preplanting treatments of dipping in some growth regulators capability and guava genotype during 2018 \& 2019 seasons.

\begin{tabular}{|c|c|c|c|c|c|c|}
\hline \multirow{3}{*}{$\begin{array}{l}\text { Dipping } \\
\text { treatments } \\
\text { Genotype } \\
\text { (seedling tree) } \\
\text { Code }\end{array}$} & \multicolumn{6}{|c|}{ Number of roots /rooted cutting } \\
\hline & \multicolumn{2}{|c|}{ 1st season } & \multirow[b]{2}{*}{ Mean * } & \multicolumn{2}{|c|}{ 2므 season } & \multirow[b]{2}{*}{ Mean * } \\
\hline & $\begin{array}{c}\text { IBA } \\
4000 \text { ppm }\end{array}$ & $\begin{array}{c}\text { TIBA } \\
\text { 100ppm }\end{array}$ & & $\begin{array}{c}\text { IBA } \\
4000 \text { ppm }\end{array}$ & $\begin{array}{c}\text { TIBA } \\
\text { 100ppm }\end{array}$ & \\
\hline 2 & $1.50 \mathrm{e}$ & $3.00 \mathrm{e}$ & $2.25 \mathrm{D}$ & $1.33 \mathrm{e}$ & $4.00 \mathrm{~d}$ & $2.66 \mathrm{E}$ \\
\hline 6 & $7.00 \mathrm{~d}$ & $13.33 \mathrm{bc}$ & 10.16 BC & $5.66 \mathrm{~cd}$ & $15.33 \mathrm{a}$ & $10.49 \mathrm{C}$ \\
\hline 7 & $10.66 \mathrm{c}$ & $12.00 \mathrm{bc}$ & $11.33 \mathrm{~B}$ & $12.00 \mathrm{~b}$ & $14.00 \mathrm{ab}$ & $13.00 \mathrm{~B}$ \\
\hline 8 & $8.00 \mathrm{~d}$ & $11.00 \mathrm{c}$ & $9.50 \mathrm{C}$ & $7.00 \mathrm{c}$ & $7.66 \mathrm{c}$ & $7.33 \mathrm{D}$ \\
\hline 10 & $14.33 \mathrm{~b}$ & $17.66 \mathrm{a}$ & $15.99 \mathrm{~A}$ & $15.00 \mathrm{a}$ & $15.66 \mathrm{a}$ & $15.33 \mathrm{~A}$ \\
\hline Mean ** & $8.30 \mathrm{~B}$ & $11.40 \mathrm{~A}$ & & $8.20 \mathrm{~B}$ & $11.33 \mathrm{~A}$ & \\
\hline
\end{tabular}

*, ** refer to specific effect of seedling tree genotype and growth regulators treatment respectively.

means of each investigated factor or their combinations followed by the same letter/s are not significantly different at $5 \%$ level.

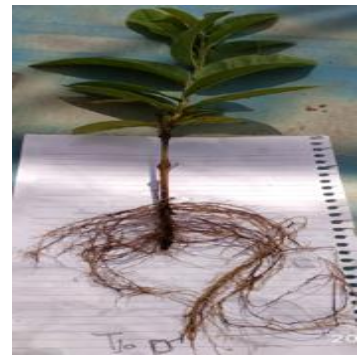

A

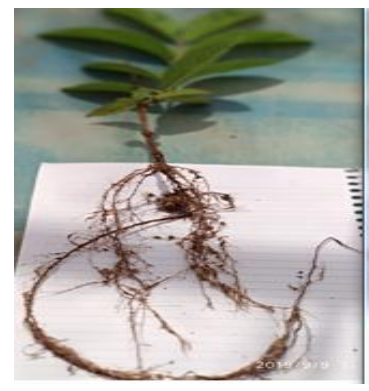

C

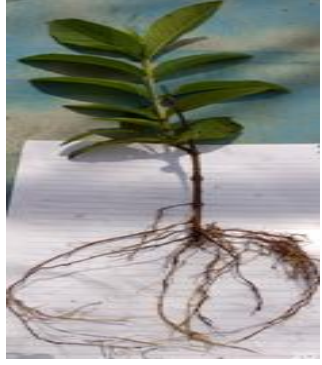

B

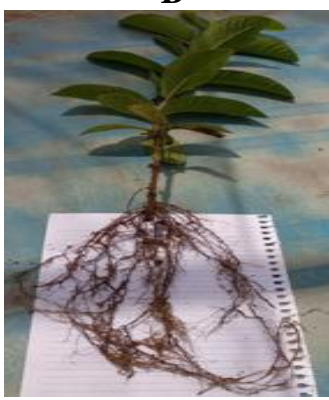

D

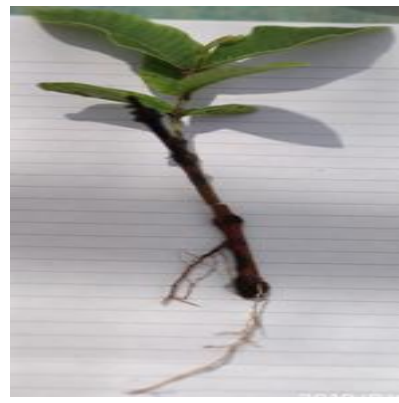

$\mathbf{E}$

Photo (1): Rooting ability of guava stem cuttings from different genotypes under various treatments. $A=10^{\text {th }}$ genotype dipped on 100ppm TIBA, B=10 ${ }^{\text {th }}$ genotype dipped on 4000ppm IBA, $C=6^{\text {th }}$ genotype dipped on $100 \mathrm{ppm}$ TIBA , $\mathrm{D}=7^{\text {th }}$ genotype dipped on 100ppm TIBA and E $2^{\text {ed }}$ genotype dipped on 4000ppm IBA. 


\section{2. Average root length:}

A. Specific effect:

Table (3) displays that, the same trend previously found with number of roots per cutting was also detected with the average root length regarding the specific effect of two investigated factors (guava genotype and preplanting dipping in growth regulators solutions). However, few exceptions were detected regarding the specific effect of guava genotype, whereas the genotype (6) was also included especially during $1^{\text {st }}$ season as the most depressive one for average root length.

\section{B. Inter action effect:}

As for the interaction effect Table (3) reveal that the specific effect of each investigated factor was directly reflected on interaction effect of their combinations. Herein, the greatest number of roots/ rooted cutting was always in significant concomitant to the $100 \mathrm{ppm}$ TIBA dipped cuttings of the genotype
(10) during both seasons, followed by dipping cutting of both genotypes (6 or 7). In $100 \mathrm{ppm}$ TIBA for the number of roots and their average length, respectively during two experimental season. On the contrary the least number of roots and the shortest ones were in closed relationship to the dipped cuttings of the $2^{\text {nd }}$ genotypes in $4000 \mathrm{ppm}$ IBA or $100 \mathrm{ppm}$ TIBA/ 4000 ppm IBA during both seasons for the number and length of roots, respectively. In addition other combinations were in between the abovementioned two extremes with on obvious tendency of the relative superiority of dipping genotype (7) cuttings and $8^{\text {th }}$ genotype cuttings in 100 ppm TIBA over the other combinations of such intermediate category during both seasons as the number of roots/ rooted cutting and their average length was concerned, respectively.

These results are in harmony with findings of Abdul Kareem et al., (2016) and Umbreen et al., (2019).

Table 3. Average root length $(\mathrm{cm})$ of guava rooted cutting for five guava genotypes succeeded to root as affected by preplanting treatments of dipping in some growth regulators and guava genotypes during 2018 \& 2019 seasons.

\begin{tabular}{|c|c|c|c|c|c|c|}
\hline \multirow{3}{*}{$\begin{array}{l}\text { Dipping } \\
\text { treatments } \\
\text { Genotype } \\
\text { (seedling } \\
\text { tree) code }\end{array}$} & \multicolumn{6}{|c|}{ Maximum root length $(\mathrm{cm})$ per rooted cutting } \\
\hline & \multicolumn{2}{|c|}{ 1'st season } & \multicolumn{4}{|c|}{$2^{\text {nd }}$ season } \\
\hline & $\begin{array}{c}\text { IBA } \\
4000 \text { ppm }\end{array}$ & $\begin{array}{c}\text { TIBA } \\
\text { 100ppm }\end{array}$ & Mean * & $\begin{array}{c}\text { IBA } \\
4000 \text { ppm }\end{array}$ & $\begin{array}{c}\text { TIBA } \\
\text { 100ppm }\end{array}$ & Mean * \\
\hline 2 & $6.16 \mathrm{f}$ & $5.00 \mathrm{f}$ & $5.58 \mathrm{E}$ & $7.16 \mathrm{e}$ & $6.33 \mathrm{e}$ & 6.74 D \\
\hline 6 & $15.00 \mathrm{e}$ & $17.00 \mathrm{e}$ & 16.00 D & $20.00 \mathrm{~cd}$ & $17.05 \mathrm{~d}$ & $18.50 \mathrm{C}$ \\
\hline 7 & $20.00 \mathrm{~d}$ & $16.33 \mathrm{e}$ & $18.16 \mathrm{C}$ & $19.66 \mathrm{~cd}$ & $16.50 \mathrm{~d}$ & $18.08 \mathrm{C}$ \\
\hline 8 & $21.33 \mathrm{~d}$ & $29.00 \mathrm{~b}$ & $5.16 \mathrm{~B}$ & $23.00 \mathrm{c}$ & $29.50 \mathrm{~b}$ & $26.25 \mathrm{~B}$ \\
\hline 10 & $24.66 \mathrm{c}$ & $36.00 \mathrm{a}$ & $30.33 \mathrm{~A}$ & $24.00 \mathrm{c}$ & $37.00 \mathrm{a}$ & 30.50 A \\
\hline Mean ** & $17.43 \mathrm{~B}$ & $20.66 \mathrm{~A}$ & & $18.76 \mathrm{~B}$ & $21.27 \mathrm{~A}$ & \\
\hline
\end{tabular}

*,** refer to specific effect of seedling tree genotype and growth regulators treatment respectively.

Means of each investigated factor or their combinations followed by the same letter/ s are not

significantly different at $5 \%$ level.

\section{3. Number of shoots per rooted cutting and their average length:}

A. Specific effect:

Data obtained during both 2018 \& 2019 experimental seasons showed that both shoots parameters (Number \& Length) followed generally the same trend regarding their response to the investigated two factors (preplanting treatment of dipping cutting in growth regulators solution \& guava genotype). Herein, no differences were observed in two shoots measurements exhibited between both TIBA \& IBA growth regulators. However, as the specific effect of guava genotype Tables (4) and (5) display that the highest values of two parameters were in closed relationship to the $10^{\text {th }}$ genotype rooted cuttings during two seasons. The opposite was found generally with $7^{\text {th }}$ genotype rooted cuttings.

\section{B. Interaction effect:}

Data obtained during both seasons displayed that the more pronounced specific effect of guava genotype associated with the light effect of preplanting cuttings were reflected directly on their interaction effect of their combinations. Since, the highest values of both shoots measurements (No. \& length) were generally in concomitant to the $10^{\text {th }}$ guava genotype rooted cuttings, regardless of the growth regulator solution used for preplanting dipping. On the contrary the least value for both shoots parameters was to great extent the $7^{\text {th }}$ genotype rooted cuttings irrespective of growth regulator used such trend was true during both seasons with the unique exception i.e., the superiority of $2^{\text {nd }}$ genotype rooted cuttings previously dipped in $100 \mathrm{ppm}$ TIBA during the $2^{\text {nd }} 2018$ season. Moreover, in most cases differences between the various combinations were relatively so slight to read level of significance.

Table 4. Number of shoots/ per guava rooted cutting of five guava genotypes successed to root as affected by preplanting treatments of dipping some growth regulators and guava genotypes during 2018 \& 2019 seasons. 


\begin{tabular}{|c|c|c|c|c|c|c|}
\hline Dipping & & Nur & of shoots & rooted cutt & & \\
\hline treatments & & & & $2^{\text {nd }}$ & son & \\
\hline $\begin{array}{l}\text { Genotype } \\
\text { (seedling } \\
\text { tree) code }\end{array}$ & $\begin{array}{c}\text { IBA } \\
4000 \mathrm{ppm}\end{array}$ & $\begin{array}{c}\text { TIBA } \\
\text { 100ppm }\end{array}$ & Mean * & $\begin{array}{c}\text { IBA } \\
4000 \mathrm{ppm}\end{array}$ & $\begin{array}{c}\text { TIBA } \\
\text { 100ppm }\end{array}$ & Mean * \\
\hline 2 & $1.50 \mathrm{~cd}$ & $2.00 \mathrm{bc}$ & $1.75 \mathrm{~B}$ & $2.50 \mathrm{a}$ & $2.00 \mathrm{a}$ & $2.25 \mathrm{~A}$ \\
\hline 6 & $1.33 \mathrm{~d}$ & $1.00 \mathrm{~d}$ & $0.88 \mathrm{C}$ & $2.00 \mathrm{a}$ & $2.00 \mathrm{a}$ & $2.00 \mathrm{~A}$ \\
\hline 7 & $1.00 \mathrm{~d}$ & $1.00 \mathrm{~d}$ & $0.83 \mathrm{C}$ & $1.00 \mathrm{~b}$ & $1.33 \mathrm{~b}$ & $1.16 \mathrm{~B}$ \\
\hline 8 & $2.00 \mathrm{bc}$ & $2.33 \mathrm{ab}$ & $1.88 \mathrm{AB}$ & $1.00 \mathrm{~b}$ & $2.00 \mathrm{a}$ & $1.50 \mathrm{~B}$ \\
\hline 10 & $2.33 \mathrm{ab}$ & $2.66 \mathrm{a}$ & $2.49 \mathrm{~A}$ & $2.33 \mathrm{a}$ & $2.33 \mathrm{a}$ & $2.33 \mathrm{~A}$ \\
\hline Mean ** & $1.63 \mathrm{~A}$ & $1.63 \mathrm{~A}$ & & $1.76 \mathrm{~A}$ & $1.93 \mathrm{~A}$ & \\
\hline
\end{tabular}

*,** refer to specific effect of seedling tree genotype and growth regulators treatment respectively.

Means of each investigated factor or their combinations followed by the same letter/s are not significantly different at $5 \%$ level.

Table 5. Shoot length $(\mathrm{cm})$ of guava rooted cutting of five guava genotypes successed to root as affected by preplanting treatments of dipping in some growth regulators and guava genotypes during 2018 and 2019 seasons.

\begin{tabular}{|c|c|c|c|c|c|c|}
\hline \multirow{3}{*}{$\begin{array}{l}\text { Dipping treatments } \\
\text { Genotype (seedling } \\
\text { tree) code }\end{array}$} & \multicolumn{6}{|c|}{ Shoot length $(\mathrm{cm})$ per rooted cutting } \\
\hline & \multicolumn{2}{|c|}{ 1st season } & \multirow[b]{2}{*}{ Mean * } & \multicolumn{2}{|c|}{$2^{\text {nd }}$ season } & \multirow[b]{2}{*}{ Mean * } \\
\hline & $\begin{array}{c}\text { IBA } \\
4000 \mathrm{ppm}\end{array}$ & $\begin{array}{c}\text { TIBA } \\
\text { 100ppm }\end{array}$ & & $\begin{array}{c}\text { IBA } \\
4000 \mathrm{ppm}\end{array}$ & $\begin{array}{c}\text { TIBA } \\
\text { 100ppm }\end{array}$ & \\
\hline 2 & $12.30 \mathrm{c}$ & $11.16 \mathrm{c}$ & $11.73 \mathrm{~B}$ & $12.83 \mathrm{e}$ & $41.83 \mathrm{a}$ & $27.33 \mathrm{~A}$ \\
\hline 6 & $22.50 \mathrm{~b}$ & $24.16 \mathrm{ab}$ & $23.33 \mathrm{~A}$ & $22.00 \mathrm{~cd}$ & $30.33 \mathrm{bc}$ & 26.16 A \\
\hline 7 & $12.33 \mathrm{c}$ & $12.33 \mathrm{c}$ & $12.33 \mathrm{~B}$ & $18.16 \mathrm{de}$ & 21.66 cde & $19.91 \mathrm{~A}$ \\
\hline 8 & $22.50 \mathrm{~b}$ & $25.83 \mathrm{ab}$ & $24.16 \mathrm{~A}$ & $28.00 \mathrm{bc}$ & $27.33 \mathrm{bc}$ & $27.66 \mathrm{~A}$ \\
\hline 10 & $24.66 \mathrm{ab}$ & $29.66 \mathrm{a}$ & $27.16 \mathrm{~A}$ & $28.00 \mathrm{bc}$ & $31.83 \mathrm{ab}$ & $29.91 \mathrm{~A}$ \\
\hline Mean ** & $18.86 \mathrm{~A}$ & $20.63 \mathrm{~A}$ & & $21.80 \mathrm{~A}$ & $30.600 \mathrm{~A}$ & \\
\hline
\end{tabular}

*, ** refer to specific effect of seedling tree genotype and growth regulators treatment respectively. Means of each investigated factor or their combinations followed by the same letter/s are not significantly different at $5 \%$ level.

2.4. Number of leaves per rooted cutting and average leaf area.

\section{A- Specific effect.}

Data obtained during both 2018\&2019 experimental seasons displayed that each parameter (No. of leaves \& average leafy area) followed its own trend regarding their response to the specific effect of two investigated of factors. Herein, the greatest number of leaves per rooted cutting was always in concomitant to the $8^{\text {th }}$ guava genotype, while the opposite was found with the both $2^{\frac{\text { nd }}{2}} \& 7 \frac{\text { th }}{\text { guava }}$ genotypes.

Differences were significant during both seasons regarding the superiority of the $10^{\text {th }}$ genotype over the other evaluated ones, which were in most cases when compared each other.

On the other hand the response of average leaf area to the specific effect of guava genotypes declared obviously a considerable shift was exhibited whereas the $10^{\text {th }}$ genotype was the superior, however differences in most cases didn't reach level of significance particularly during $1^{\text {st }} 2018$ experimental seasons.
Meanwhile, both leaves measurements (No. \& leafy area) followed the same trend regarding their. Response to the preplanting dipping of stem cuttings in growth regulators solutions. Hence the $100 \mathrm{ppm}$ TIBA solution was significantly effective then 4000 ppm IBA solution. Differences were relatively moderate but significant during both 2018 \& 2019 experimental seasons.

\section{B- Interaction effect.}

Data obtained during both seasons revealed that the specific effect of each investigated factor was direct by reflected on interaction effect of their combinations. Consequently the greatest number of leaves per rooted cutting was generally coupled with both combinations (dipping cuttings of $8^{\text {th }}$ genotype in either 4000 ppm IBA or 100 ppm TIBA) and dipped cuttings of the same guava genotype in $100 \mathrm{ppm}$ TIBA during $1^{\text {st }}$ and $2^{\text {nd }}$ seasons, respectively.

It was generally observed that the differences between the different combinations in most cases were not so pronounced to reach level of significance. On the contrary, the least number of leaves per rooted 
cutting was coupled to the $2^{\text {nd }}$ guava genotype cutting dipped in $4000 \mathrm{ppm}$ IBA. The absent of significance with comparing the different combinations could be logically explained depending upon the moderate or slight differences between most members of each investigated factor as previously mentioned.

As for the interaction effect on average leaf area Table (7) displays that the widest leaf area value was in concomitant to those of guava rooted cuttings produced by dipping $10^{\text {th }}$ genotype stem cuttings in $100 \mathrm{ppm}$ TIBA solution. However, differences in most cases didn't reach significance level particularly as compared to those of (dipping cuttings of both $8^{\text {th }} \&$ $6^{\text {th }}$ guava genotypes in $100 \mathrm{ppm}$ TIBA) and (4000 ppm IBA dipped cuttings of both $2 \frac{\text { nd }}{2} \& 10^{\text {th }}$ genotypes) during both seasons.

The reverse (the least leaf area was generally shown with the 4000 ppm IBA cuttings of $7^{\text {th }}$ genotype. Other combinations were in between.

This result is in general agreement with those reported by Maurya et al. (2012); Manga and Jholgiker (2017) and Prakash et al., (2018).

Table 6. Number of leaves per rooted cutting of five guava genotypes successed to root as affected by preplanting treatments of dipping in some growth regulators and guava genotypes during 2018 \& 2019 seasons.

\begin{tabular}{|c|c|c|c|c|c|c|}
\hline \multirow{3}{*}{$\begin{array}{l}\text { Dipping } \\
\text { treatments } \\
\text { Genotype } \\
\text { (seedling } \\
\text { tree) code }\end{array}$} & \multicolumn{6}{|c|}{ Number of leaves/rooted cutting } \\
\hline & \multicolumn{2}{|c|}{ 1st season } & \multirow[b]{2}{*}{ Mean * } & \multicolumn{2}{|c|}{$2^{\text {nd }}$ season } & \multirow[b]{2}{*}{ Mean * } \\
\hline & $\begin{array}{c}\text { IBA } \\
4000 \text { ppm }\end{array}$ & $\begin{array}{c}\text { TIBA } \\
\text { 100ppm }\end{array}$ & & $\begin{array}{c}\text { IBA } \\
4000 \text { ppm }\end{array}$ & $\begin{array}{c}\text { TIBA } \\
\text { 100ppm }\end{array}$ & \\
\hline 2 & $8.33 \mathrm{e}$ & 10.66 cde & $9.49 \mathrm{C}$ & $9.00 \mathrm{c}$ & $14.33 \mathrm{~b}$ & $16.16 \mathrm{~B}$ \\
\hline 6 & $12.66 \mathrm{abc}$ & $13.00 \mathrm{abc}$ & $12.83 \mathrm{~B}$ & $12.66 \mathrm{bc}$ & $14.33 \mathrm{~b}$ & $13.49 \mathrm{~B}$ \\
\hline 7 & $9.00 \mathrm{de}$ & $14.66 \mathrm{ab}$ & $11.83 \mathrm{BC}$ & $14.00 \mathrm{~b}$ & $11.00 \mathrm{bc}$ & $12.50 \mathrm{~B}$ \\
\hline 8 & $16.00 \mathrm{a}$ & $15.00 \mathrm{ab}$ & $15.50 \mathrm{~A}$ & $12.66 \mathrm{bc}$ & $24.00 \mathrm{a}$ & $18.33 \mathrm{~A}$ \\
\hline 10 & $12.00 \mathrm{bcd}$ & $13.00 \mathrm{abc}$ & $12.50 \mathrm{~B}$ & $11.66 \mathrm{bc}$ & $11.00 \mathrm{bc}$ & 11.33 B \\
\hline Mean *: & $11.60 \mathrm{~B}$ & $13.26 \mathrm{~A}$ & & 12.00 B & $14.93 \mathrm{~A}$ & \\
\hline
\end{tabular}

*, ** refer to specific effect of seedling tree genotype and growth regulators treatment respectively. Means of each investigated factor or their combinations followed by the same letter/s are not significantly different at $5 \%$ level

Table 7. Average leaf area per cutting of guava rooted cutting for five guava genotypes successed to root as affected by preplanting treatments of dipping in some growth regulators and guava genotypes during 2018 $\& 2019$ seasons.

\begin{tabular}{|c|c|c|c|c|c|c|}
\hline \multirow{3}{*}{$\begin{array}{l}\text { Dipping } \\
\text { treatments } \\
\text { Genotype } \\
\text { (seedling } \\
\text { tree) code }\end{array}$} & \multicolumn{6}{|c|}{ Average leaf area/ rooted cutting } \\
\hline & \multicolumn{2}{|c|}{ 1t season } & \multirow[b]{2}{*}{ Mean * } & \multicolumn{2}{|c|}{ 2nd season } & \multirow[b]{2}{*}{ Mean * } \\
\hline & $\begin{array}{c}\text { IBA } \\
4000 \mathrm{ppm}\end{array}$ & $\begin{array}{c}\text { TIBA } \\
\text { 100ppm }\end{array}$ & & $\begin{array}{c}\text { IBA } \\
4000 \mathrm{ppm}\end{array}$ & $\begin{array}{c}\text { TIBA } \\
\text { 100ppm }\end{array}$ & \\
\hline 2 & 15.99 a-d & $14.42 \mathrm{~cd}$ & $15.20 \mathrm{~A}$ & $17.45 \mathrm{ab}$ & $14.03 \mathrm{~cd}$ & $15.74 \mathrm{~B}$ \\
\hline 6 & $14.23 \mathrm{~cd}$ & $16.59 \mathrm{abc}$ & $15.41 \mathrm{~A}$ & $15.12 \mathrm{bcd}$ & $16.96 \mathrm{abc}$ & $16.04 \mathrm{AB}$ \\
\hline 7 & $14.00 \mathrm{~d}$ & $15.57 \mathrm{bcd}$ & $14.78 \mathrm{~A}$ & $12.21 \mathrm{~d}$ & $15.77 \mathrm{bc}$ & $13.99 \mathrm{~B}$ \\
\hline 8 & $16.12 \mathrm{a}-\mathrm{d}$ & $17.67 \mathrm{ab}$ & $16.89 \mathrm{~A}$ & $13.91 \mathrm{~cd}$ & $17.13 \mathrm{abc}$ & $15.52 \mathrm{~B}$ \\
\hline 10 & $13.74 \mathrm{~d}$ & $18.41 \mathrm{a}$ & $16.07 \mathrm{~A}$ & $16.71 \mathrm{abc}$ & $19.09 \mathrm{a}$ & $17.90 \mathrm{~A}$ \\
\hline Mean ** & 14.81 B & $16.53 \mathrm{~A}$ & & $15.08 \mathrm{~B}$ & $16.59 \mathrm{~A}$ & \\
\hline
\end{tabular}

*, ** refer to specific effect of seedling tree genotype and growth regulators treatment respectively. Means of each investigated factor or their combinations followed by the same letter/s are not significantly different at $5 \%$ level .

\section{5. Survival percentage:}

The survival percentage of translocated rooting cuttings of the five guava genotypes succeeded to root after 12 weeks of their transplanting in response to specific and interaction effects of two studied factors (guava genotype \& dipping their basal cuttings in either 4000 ppm IBA or 100 ppm TIBA) and their combinations were evaluated. Data obtained during both 2018 \& 2019 experimental seasons were tabulated in Table (8) and illustrated by photo (2).

\section{A- Specific effect:}

As for the specific effect of growth regulator solution used for dipping cuttings base preplanting it is quite evident that $100 \mathrm{ppm}$ TIBA solution exceeded significantly 4000 ppm IBA solution during both seasons. However, the specific effect of guava genotype was also pronounced whereas the $10^{\text {th }}$ genotype was statistically the superior with $100 \%$ survived transplanted rooted cuttings during two seasons of study. On the contrary, both $2^{\text {nd }} \& 7^{\text {th }}$ guava genotypes were significantly the inferior during 2018 \& 2019 experimental seasons, respectively. In addition two other guava genotypes i.e, $6^{\text {th }} \& 8^{\text {th }}$ were in between the aforesaid two extremes.

The present result regarding the specific effect of either guava genotype and growth regulators goes in line with the previously discussed data particularly (No. of roots/cutting \& average length), (No. of shoots \& their length) and average leaf area 
whereas a positive relationship between such measurements from one hand and obviously observed.

Besides, the anatomical examination as will be shown later gave support to the detected trend of survival \% pertaining the specific effect of two studied factors. Whereas, the $100 \mathrm{ppm}$ TIBA dipped cuttings of the $10^{\text {th }}$ genotype pointed out that all adventurous roots were initiated from cambium layer with a maximum number (4) three of them had a distinguished tissues showed clearly vascular cylinder tissues which facilate their vascular connection to the stem (cutting) and consequently reflected positively on their higher propability to survive.

\section{B- Interaction effect:}

It is quite clear that the specific effect of each investigated factor was directly reflected on their combinations. Herein, the $10^{\text {th }}$ genotype cuttings regardless of growth regulators used for preplanting dipping resulted significantly in the greatest survival $\%(100 \%)$ during two seasons. Besides, 100 ppm TIBA dipped cuttings of both $2^{\text {nd }} \& 6^{\text {th }}$ guava genotypes during two seasons exhibited also the same value (100\%). On the opposite 4000 ppm IBA dipped cuttings of $2^{\text {nd }}$ guava genotype (during both seasons) and 100 ppm TIBA dipped cuttings of $7^{\text {th }}$ genotype (during $2^{\text {nd }}$ seasons) were significantly the inferior. In addition other combinations were in between with a relative tendency of variance not only from one combination to other but also from one season to another.

This result is in general agreement with those reported by Abdul Kareem et al., (2016).

Table 8. Survival\% of guava rooted cuttings of five genotypes succeeded to root as affected by preplanting treatments of dipping in some growth regulators and guava genotype capability during 2018 \& 2019 seasons.

\begin{tabular}{|c|c|c|c|c|c|c|}
\hline \multirow{3}{*}{$\begin{array}{l}\begin{array}{c}\text { Dipping } \\
\text { treatments }\end{array} \\
\text { Genotype } \\
\text { (seedling } \\
\text { tree) code }\end{array}$} & \multicolumn{6}{|c|}{ Survival \% of guava rooted cuttings } \\
\hline & \multicolumn{2}{|c|}{2018 season } & \multirow[b]{2}{*}{ Mean * } & \multicolumn{2}{|c|}{2019 season } & \multirow[b]{2}{*}{ Mean * } \\
\hline & $\begin{array}{c}4000 \mathrm{ppm} \\
\text { IBA }\end{array}$ & $\begin{array}{c}\text { 100ppm } \\
\text { TIBA }\end{array}$ & & $\begin{array}{c}4000 \text { ppm } \\
\text { IBA }\end{array}$ & $\begin{array}{c}\text { 100ppm } \\
\text { TIBA }\end{array}$ & \\
\hline 2 & $16.67 \mathrm{e}$ & $50.00 \mathrm{c}$ & $33.33 \mathrm{D}$ & $50.00 \mathrm{~d}$ & $100.00 \mathrm{a}$ & $75.00 \mathrm{C}$ \\
\hline 6 & $66.67 \mathrm{~b}$ & $50.00 \mathrm{c}$ & $58.33 \mathrm{BC}$ & $66.66 \mathrm{c}$ & $100.00 \mathrm{a}$ & 83.33 B \\
\hline 7 & $33.33 \mathrm{~d}$ & $66.67 \mathrm{~b}$ & $50.00 \mathrm{C}$ & $66.66 \mathrm{c}$ & $44.44 \mathrm{~d}$ & $55.55 \mathrm{D}$ \\
\hline 8 & $50.00 \mathrm{c}$ & $66.67 \mathrm{~b}$ & $58.33 \mathrm{BC}$ & $83.33 \mathrm{~b}$ & $83.33 \mathrm{~b}$ & 83.33 B \\
\hline 10 & $100.00 \mathrm{a}$ & $100.00 \mathrm{a}$ & $100.00 \mathrm{~A}$ & $100.00 \mathrm{a}$ & $100.00 \mathrm{a}$ & $100.00 \mathrm{~A}$ \\
\hline Mean ** & $53.33 \mathrm{~B}$ & $66.66 \mathrm{~A}$ & & $73.33 \mathrm{~B}$ & $85.55 \mathrm{~A}$ & \\
\hline
\end{tabular}

*,**, refer to specific effect of guava genotype and growth regulators, respectively. Means of each investigated factor or their combinations followed by the same letter/s are not significantly different at $5 \%$ level.

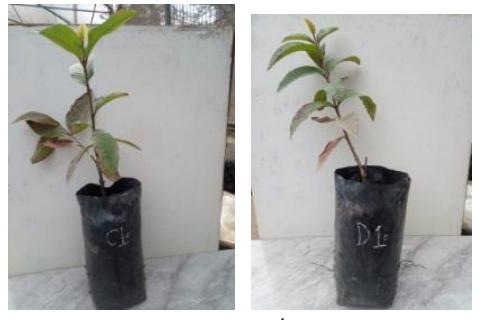

A

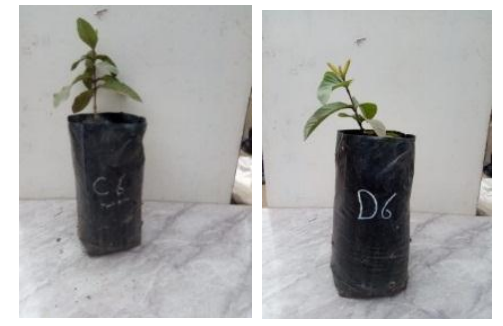

D

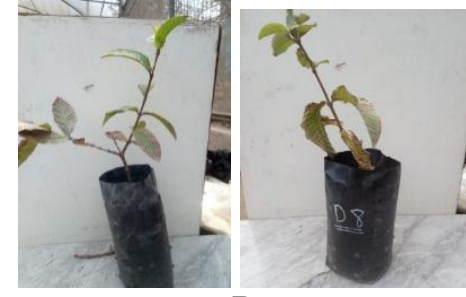

B

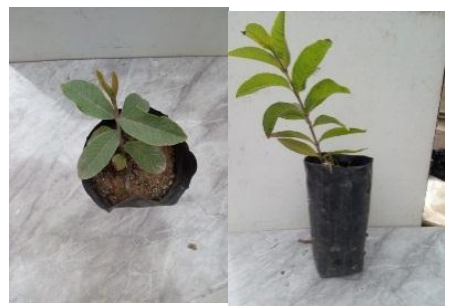

$\mathbf{E}$

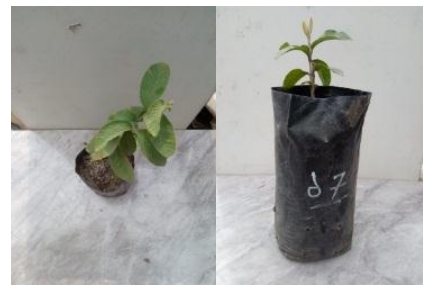

C

Photo (2): Survival and develop transplants produced from different guava genotypes.

$\mathrm{A}=10^{\text {th }}$ genotype, $\mathrm{B}=8^{\text {th }}$ genotype, $\mathrm{C}=7^{\text {th }}$ genotype, $\mathrm{D}=6^{\text {th }}$ genotype and $\mathrm{E}=2^{\mathrm{ed}}$ genotype.

-Anatomical initiation of adventitious roots:

The anatomical initiation origin of the adventitious from the soft wood stem cuttings of five guava genotypes after dipping in 4000 ppm IBA \& 100 ppm TIBA was illustrated by photos (3), (4), (5) and (6).

The microscopic examination revealed that initiation origin of the adventitious roots followed one 
of the following cases: $1^{\text {st }}$ case, whereas the adventitious roots were anatomically initiated as an extent of the cortex cell layer and their tissues were completely comprised of parenchyma cells and the vascular bundles were entirely absent as shown in photos (3) which dealing with the 4000 ppm dipped cuttings of both $6 \& 7^{\text {th }}$ genotypes. $2^{\text {nd }}$ case, the adventurous roots were initiated as an extension of both pith tissue sides with no sign of vascular connection to the stem which was entirely ceased just at cutting edge. Such pattern was observed in the 100 ppm TIBA dipped cuttings of the $6^{\text {th }}$ guava genotype as shown in photo (4). $3^{\text {rd }}$ pattern of root initiation was dealing with the 4000 ppm IBA dipped cuttings of the four $2^{\text {nd }}, 6^{\text {th }}, 7^{\text {th }}$ and $10^{\text {th }}$ guava genotypes as shown in photo (5) whereas roots tissues contained parenchyma cells only. $4^{\text {th }}$ case was represented by the $10^{\text {th }}$ guava genotype cuttings dipped in $100 \mathrm{ppm}$ TIBA, whereas three roots of well differentiated tissues i.e., having obviously vascular cylinders photo (6).
Conclusively, all treatments i.e., combinations (genotype $\mathrm{x}$ growth regulator) which succeeded to root declared that their adventitious roots initiated from cambium layer except dipped cuttings of $6 \& 7^{\text {th }}$ genotypes in $4000 \mathrm{ppm}$ IBA and the $6^{\text {th }}$ genotype cuttings dipped in 100 ppm TIBA, whereas their roots were initiated from cortex and pith, respectively. On the other hand the $100 \mathrm{ppm}$ TIBA dipped cuttings of $10^{\text {th }}$ genotype induced four adventurous roots initiated from the cambium layer three of them having with differentiated tissues with vascular system. Consequently the 100 ppm TIBA treated cuttings of the $10^{\text {th }}$ guava genotype exhibited the most desirable anatomical feature and the well performed adventitious roots (number and were vascular connection) which certainly reflected positively on the higher survival $\%$ of their developed rooted cuttings. These results are in harmony with findings of Hosny (1974); Aou- Amara (1976); El- Iraqy (1994) and Bakry (1998).

Table 9. Cross section anatomical examinations of guava soft wood cuttings dipped in IBA \& TIBA solutions for five genotypes succeeded to root.

\begin{tabular}{|c|c|c|c|c|c|c|c|c|c|c|}
\hline \multirow{2}{*}{$\begin{array}{l}\text { Treatments } \\
\text { Measurements } \\
\text { (microns) }\end{array}$} & \multicolumn{5}{|c|}{ IBA (4000 ppm) } & \multicolumn{5}{|c|}{ TIBA (100 ppm) } \\
\hline & 2 & 6 & 7 & 8 & 10 & 2 & 6 & 7 & 8 & 10 \\
\hline $\begin{array}{l}\text { Diameter of } \\
\text { whole stem }\end{array}$ & 3420.00 & 5469.00 & 3637.00 & 4086.00 & 4608.00 & 5130.00 & 5193.00 & 4709.00 & 5056.5 & 4333.00 \\
\hline $\begin{array}{l}\text { Periderm } \\
\text { thickness }\end{array}$ & 112.50 & 76.50 & 108.00 & 81.00 & 90.00 & 90.00 & 58.50 & 90.00 & 135.00 & 90.00 \\
\hline $\begin{array}{c}\text { Cortex } \\
\text { thickness }\end{array}$ & 108.00 & 279.00 & 99.00 & 189.00 & 180.00 & 315.00 & 180.00 & 145.00 & 145.00 & 155.00 \\
\hline $\begin{array}{c}\text { Outer } \\
\text { phloem } \\
\text { thickness }\end{array}$ & 90.00 & 90.00 & 85.50 & 90.00 & 90.00 & 180.00 & 135.00 & 135.00 & 185.00 & 153.00 \\
\hline $\begin{array}{l}\text { Cambium } \\
\text { thickness }\end{array}$ & 99.00 & 23.40 & 22.50 & 27.00 & 31.50 & 180.00 & 90.00 & 184.50 & 164.25 & 189.00 \\
\hline $\begin{array}{c}\text { xylem } \\
\text { thickness }\end{array}$ & 747.00 & 1264.00 & 855.00 & 1026.00 & 1260.00 & 810.00 & 1404.00 & 1057.50 & 1035.00 & 1170.00 \\
\hline $\begin{array}{c}\text { Inner } \\
\text { phloem } \\
\text { thickness }\end{array}$ & 82.50 & 191.00 & 137.25 & 270.00 & 270.00 & 99.00 & 117.00 & 180.00 & 144.00 & 180.00 \\
\hline $\begin{array}{l}\text { Mean pith } \\
\text { thickness }\end{array}$ & 450.00 & 1620.00 & 1023.00 & 720.00 & 765.00 & 1305.00 & 1260.00 & 1125.00 & 1440.00 & 900.00 \\
\hline $\begin{array}{c}\text { Thickness of } \\
\text { widest xylem } \\
\text { vessel in } \\
\text { vascular } \\
\text { cylinder. }\end{array}$ & 45.00 & 63.00 & 38.25 & 54.00 & 54.00 & 36.00 & 49.50 & 40.50 & 31.50 & 45.00 \\
\hline $\begin{array}{l}\text { No. of the } \\
\text { roots }\end{array}$ & - & 1.00 & 1.00 & 1.00 & 1.00 & 1.00 & - & 1.00 & 1.00 & 4.00 \\
\hline $\begin{array}{l}\text { Mean length } \\
\text { of the root }\end{array}$ & - & 810.00 & 216.00 & 900.00 & 1620.00 & 2160.00 & - & 1540.00 & 2430.00 & 1514.00 \\
\hline $\begin{array}{l}\text { Mean width } \\
\text { of the root }\end{array}$ & - & 1080.00 & 540.00 & 540.00 & 1800.00 & 1080.00 & - & 1400 & 1350 & 640.20 \\
\hline
\end{tabular}




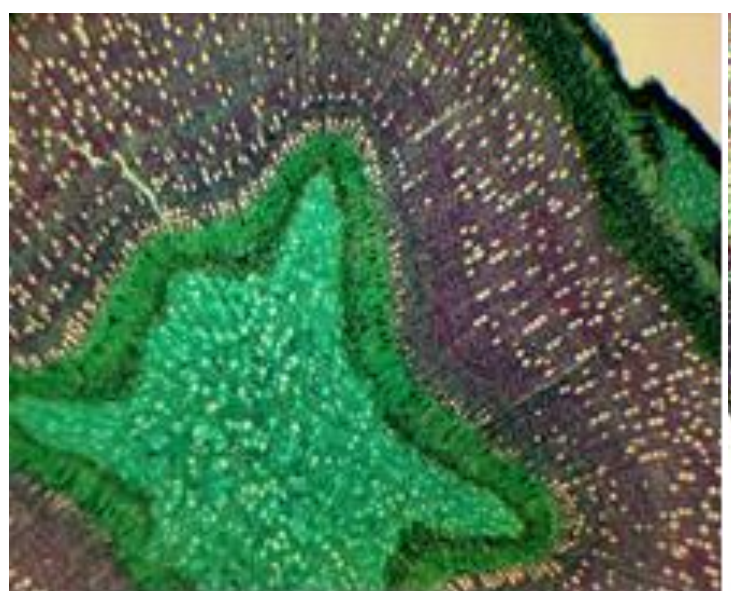

A

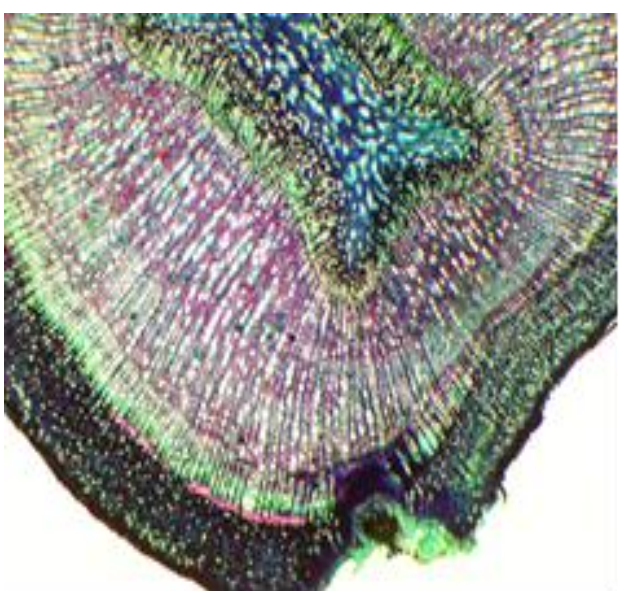

B

Photo (3): Cross section examination of guava soft wood stem cuttings dipped in (IBA \& TIBA) for five genotypes succeeded to Root: A (genotype 6 cuttings dipped in 4000 ppm IBA. B ( $7^{\text {th }}$ genotype cuttings dipped in 4000 ppm IBA).

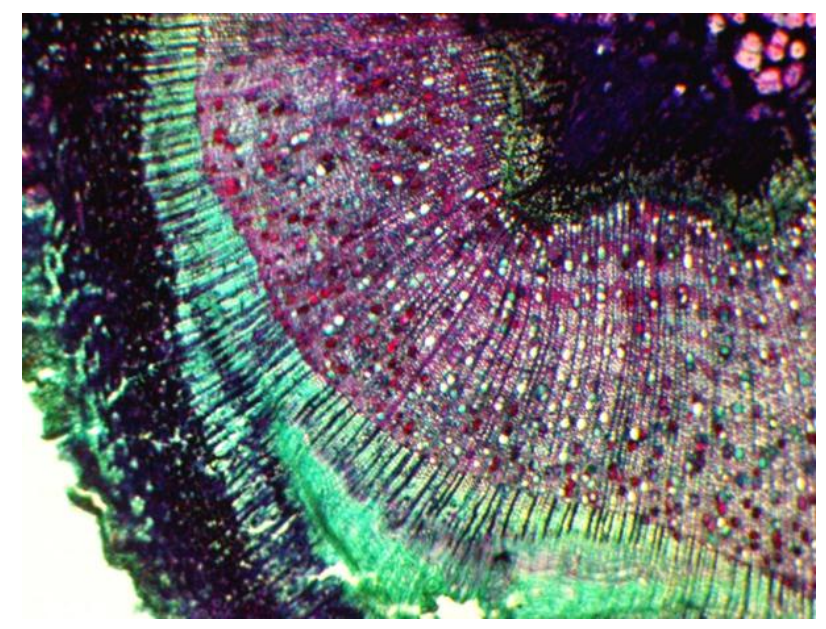

Photo (4): Cross section examination of guava soft wood stem cuttings dipped in (IBA \& TIBA) for five genotypes succeeded to root 100 ppm TIBA treated cuttings of genotype $6^{\text {th }}$.

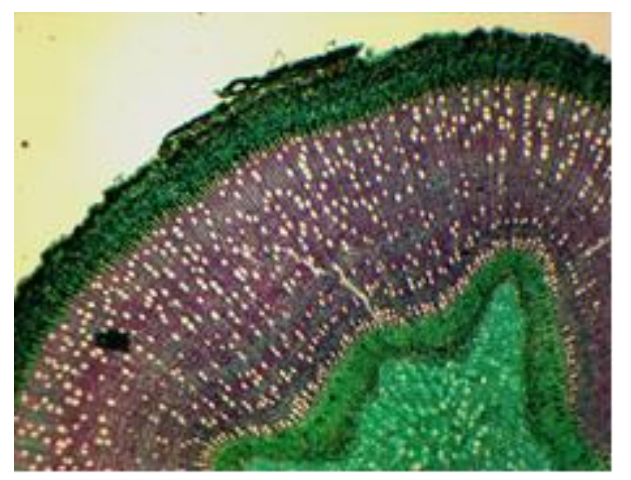

A

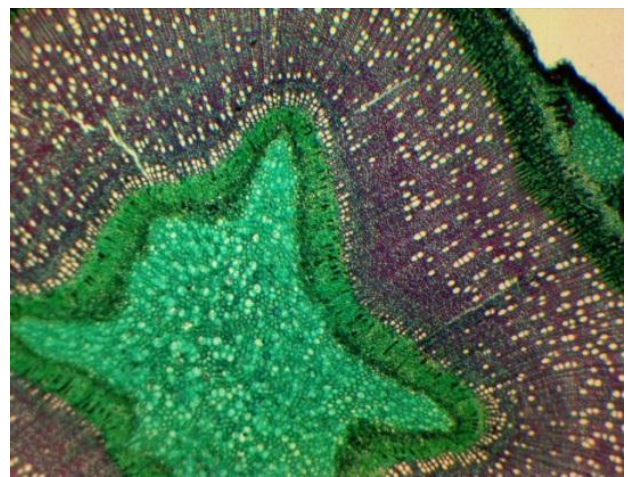

B 

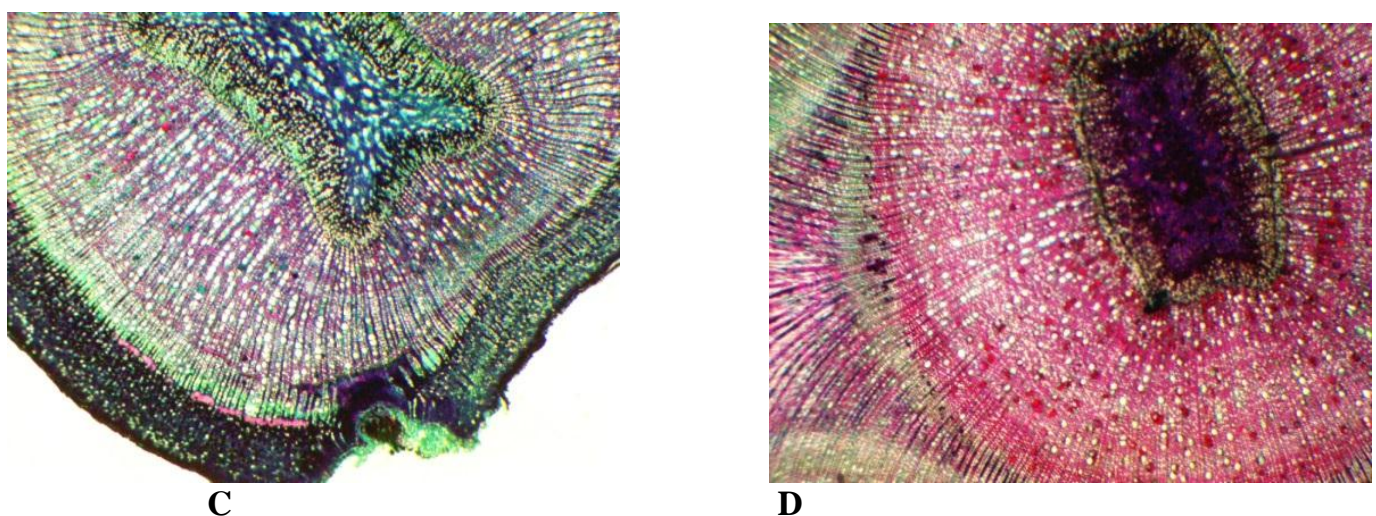

Photo (5): Cross section examination of guava soft wood cuttings dipped in $4000 \mathrm{ppm}$ IBA for $2^{\text {nd }}, 6^{\text {th }}, 7^{\text {th }}$ and $10^{\text {th }}$ genotypes (A, B, C and $\mathrm{D}$, respectively).

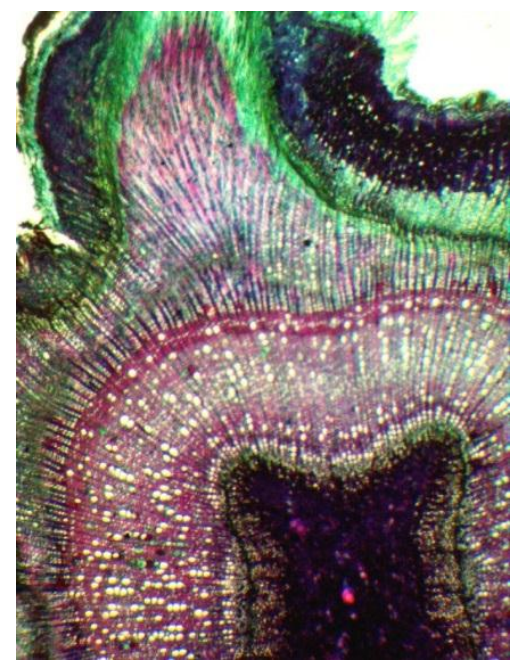

Photo (6): Cross section examination of guava soft wood cuttings dipped in 100 ppm TIBA for $10^{\text {th }}$ genotype.

\section{References}

Abdul Kareem, A. M.; Shafqat, S.; Shoaib, U. R.; Umbreen, S. and Muhammad, N. (2016): Effect of different concentrations of IBA on rooting of Guava Psidium guajava L. in low tunnel under shady situation. Journal of Agriculture and Environment for International Development JAEID - 110 (2)

Abdullah, A. T.; Hossain, M. A.; Bhuiyan, M. K. (2006): Clonal propagation of guava (Psidium guajava L.) by stem cutting from mature stock plants. Journal of Forestry Research,17(4):301304.

Abu-Amara, N. M. (1976): Physiological studies on the rooting ability of guava cutting M. Sc. Thesis. Fac. Agric. Ain Shams Univ. Egypt.

Bacarin, M. A.; Benincasa, M. P.; Andrade, V. M. and Pereira, F. M. (1994): Aerial Rooting of Guava Psidium guajava L.: effect of butyric acid IBA on root initiation. Sci. St. Paul. 221: 71-79.

Bakry, KH. A. (1998): Physiological and histological studies on vegetative propagation of mango and pecan. Ph-D., Thesis, Faculty of Agric., Zagazig Univ. Benha branch Egypt.

Boora, R. S. (2012): Improvement in guava (Psidium guajava L.) A review. Agric. Rev., 33(4):341-349.

El-Iraqy, M. A. (1994): Physiological studies on the propagation of guava M.Sc. Thesis Faculty of Agric., Zagazig Univ. Egypt.

Hartmann, H. T. (1969): Some physiological factors involved in propagation by hardwood cuttings. Proc. Intern. Pl. Prop. Soc., 19:108- 114.

Hosny, F. A. (1974): Effect of some growth regulators on Globle artichoke, M.Sc. Thesis Fac. of agric., Al-Azhar Univ., Egypt.

Johanson, D. A. (1940): Plant micro technique. $5^{\text {th }}$ ed. Mc-Graw - Hill book company, INC. New York, p.p. 523.

Kareem, A.; Jaskani, M. J.; Fatima, B. and Sadia, B. (2013): Clonal multiplication of guava through softwood cuttings under mist conditions. Pak. J. Agri. Sci., Vol. 50(1): 23-27.

Manga, B. and Jholgiker, P. (2017): Studies on Performance of Softwood Grafting in Guava (Psidium guajava L.) cv. Sardar as Influenced by 
Different Shade Intensity. Int. J Curr. Microbiol. App. Sci. 6(6):2792-2795.

Maurya, R. and Ray, N.; Chavda, J. Chauhan, V. and Patil, A. (2012): Evaluation of different organic media and water holding materials with IBA on rooting and survival of layering in guava (Psidium guajava L.)cv. Allahabad Safeda. Asian Journal of Horticulture., 7(1):44-47.

Minessy, F. A.; Taha, A. A. and El-Azab, E. M. (1967): Studies on propagation on guava. Alex. J. Agric. 15:225-244.

Prakash, M. S.; Rajangam, J.; Swaminathan, V. and Venkatesan, K.; (2018): Effect of Plant Growth Regulators on Rooting and Sprouting of Different Stem Cuttings of Guava (Psidium guajava L.) cv. Lucknow-49 under Mist Chamber Condition. Madras Agric. J., 105 (7-9): 336-340.

Samaan, L. G.; EL-Dengawy, E. F. and EL-Zayat, M. E. (2010): Response of hard wood stem $1-24$. cuttings of guava (Psidium guajava L.) to various growth and root promoting regulators. J. of Plant Production, Vol. 1 (2): $301-317$.

Snedecor, G. W. and Cochran, W. G. (1980): Statistical Methods. Oxford and J.B.H. publishing com. 7th edition, 593.

Souidan, A. A.; Zayed, M. and Dessouky, M. T. (1995): A study on improving the rooting of. Ficus elastica var. decora stem cuttings. J. Agri. Sci. Cairo 40(2), 821-829.

Umbreen, S· ; Abdul, K. ; Khadija, A. ; Shah, Z. ; Allah, D. ; Qudsia, Y. and Phoebe, C. (2019): Effects of Auxin and Media Additives on the Clonal Propagation of Guava Cuttings (Psidium guajava L.) Var. Chinese Gola. J. Agri. Sci. Food Res., Vol. 10 Iss. 1 No: 265.

Waller, A. and Duncan, D. B. (1969): Multiple ranges and multiple tests. Biometrics, 11:

\footnotetext{
دراسات على التكاثر الخضرى لبعض أشجار الجوافة البذرية وتأثرها بتراكيبها الوراثية ويعض منظمات النمو

محمد محمد شرف 1 - محمد عبدالوهب خميس 1 - خالد على بكرى 1 - وفاء توفيق سعيد 2 - اسامة محمد الطراوى 2

1 قسم البساتين - كلية الزراعة بمشتهر - جامعة بنها بكرئ

2 معهد بحوث البساتين مركز البحوث الزراعية

أجريت هذه الدراسة بمعهد بحوث البساتين- مركز البحوث الزراعية -محافظة الجيزة- مصر خلال الموسمين التجريبيين 2018 و

2019 لبحث إمكانية استخدام العقل الساقية الخشبية ذات الاوراق لعدد 10 من اشجار الجوافة البذرية في إكثارها خضريا. حيث نم دراسة قدرة العقل

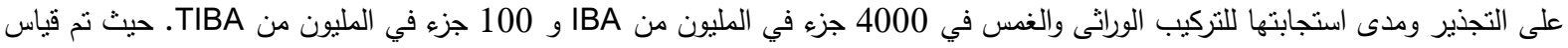

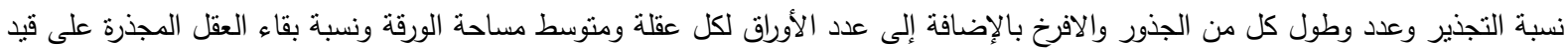
الحياة ـ اوضحت البيانات التي تم الحصول عليها خلال الموسمين ان عقل خمسة طرز وراثية فقط (شجرة بذرية) نجحت في التجذير بينما فثلت الخمس الأخرى تمامًا. من ناحية أخرى اختلفت نسبة تجذير العقل للأنماط الجينية الخمسة من شجرة إلى أخرى حيث كانت الثجرة رقم 10 متفوقة

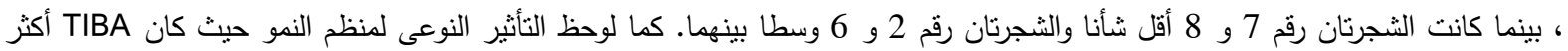
فعالية من IBA خاصة خلال الموسم الثاني. وكانت التركيبة الأكثر فاعلية مرتبطة بالعقل الماخوذة من الثجرة رقم 10 والمغموسة في في المليون TIBA يليها العقل الماخوذة من نفس الأتجار والمعاملة باندول حمض البيوتريك بتركيز 4000جزء في المليون. وكانت العقل الماخوذة

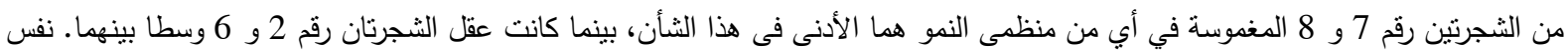
الاتجاه كان واضحا مع قياسات النمو المختلفة للعقل التى جذرت مع اسنثاءات قليلة تم ملاحظاتها خلاد الموسمين. وقد ايدت القياسات النتريحية هذه النتائج حيث أظهرت عقل الثجرة رقم 10 المغموسة في 100 جزء في المليون TIBA وجود أربعة جذور بدأت من طبقة الكامبيوم ، ثناثة منها ذات أنسجة منمايزة مع اتصال وعائي. وبالتالي فإن عقل الثجرة رقم 10 والمغموسة في 100 جزء في المليون TIBA أظهرت الميزة التشريحية المرغوبة والجذور العرضية جيدة الأداء (العدد والاتصال الوعائي) والتي نتعكس بالتأكيد بشكل إيجابي على نسبة البقاء على قيد الحياة.
} 